\title{
Development of a self-proliferating Leydig cell line: A hyper-sensitive E-screening model
}

\author{
JAMES W. DuMOND Jr ${ }^{1}$, KAMALESHWAR P. SINGH ${ }^{1}$ and DEODUTTA ROY ${ }^{2}$ \\ ${ }^{1}$ Department of Biology, Texas Southern University, Houston, TX 77004; ${ }^{2}$ Department of Environmental \\ and Occupational Health Sciences, Florida International University, Miami, FL 33199, USA
}

Received July 15, 2005; Accepted October 11, 2005

\begin{abstract}
The mechanisms of estrogenic endocrine disruption on the male reproductive tract are poorly understood. In order to examine estrogenic properties of xenobiotic chemicals on male tissues, we have developed a mouse Leydig cell line (TM3-SF) that self-proliferates under serum-free conditions. This cell line was derived from ATCC's cell line, TM3. The development of TM3-SF was accomplished over a 4-month period by a progressive serum starvation of the original TM3 cells. The newly established cell line was maintained under serum-free conditions for 20 passages prior to testing. Sensitivity of the TM3-SF cells to estrogens was assayed by cell proliferation studies. A total of four compounds, diethylstilbestrol (DES), 17ß-estradiol, 17 $\alpha$-estradiol, and Bis-phenol A, were tested. Significant increases in cell proliferation occurred at various concentrations ranging from $1 \mathrm{pg} / \mathrm{ml}$ to $100 \mathrm{ng} / \mathrm{ml}$ for all four compounds. The order of potency observed was DES $>$ Bis-phenol A $>17 \beta$-estradiol and $>17 \alpha$ estradiol. In addition, we investigated the mechanism for the self-proliferative properties of TM3-SF. The results of these trials indicate that either inhibin or activin is a primary growth factor for this cell line as a 50\% inhibition of growth was noted when cell cultures were exposed to the anti-ßa subunit of inhibin/activin. Furthermore, the addition of the anti-ßa subunit of inhibin/activin blocked the DES-induced proliferation of TM3-SF. We conclude that the growth of TM3-SF cells is estrogen sensitive and that either inhibin or activin is involved in the self-regulation of growth.
\end{abstract}

\section{Introduction}

Interest in the role of environmental estrogens has increased during the last 15 years. This interest is the result of the identification of chemicals with estrogenic properties within our environment (1-6). Exposure to estrogenic chemicals has been implicated as a causal factor for decreases in sperm

Correspondence to: Dr James W. DuMond Jr, Department of Biology, Texas Southern University, 210 Nabrit Science Building, 3100 Cleburne Avenue, Houston, TX 77004, USA

E-mail: dumond_jw@tsu.edu

Key words: estrogen, testis, cell proliferation, activin, inhibin count, increases of hypospadias, and increased incidence of testicular cancer (7-16). In animal models, estrogen treatment can induce cancer in specific target tissue (17-19). Estrogen exposure in man results in testicular atrophy when administered at pharmacological doses (20-23). Furthermore, there are clinical cases of estrogen sensitive and/or estrogen secreting Leydig cell tumors (24-29).

The recent resurgence of interest in environmental estrogenic chemicals has resulted in the use of the E-screen assay that tests a chemical's ability to induce cell proliferation (30). MCF-7 cells, cloned from a human breast tumor, have been the primary choice for the E-screen assay. While the bulk of research on environmental estrogens has focused on the role they may play in breast cancer, interest has expanded to other target tissues such as testis, kidney, and liver in more recent years. This has resulted in the need and therefore the development of non-breast cell lines that are estrogen sensitive. We have previously shown that the normalized mouse Leydig cell line, TM3, is estrogen sensitive $(31,32)$. However, our previous studies have failed to detect a significant increase in the proliferative response when TM3 cells are exposed to relatively weak estrogens (Du Mond and Roy, The Society of Toxicology International Conference, New Orleans, LA, 1998; Du Mond and Roy, The American Association for Cancer Research International Conference, Philadelphia, PA, 1998).

In our previous studies, we have revealed TM3's ability to proliferate for short periods of time after the growth medium was replaced with an unsupplemented serum-free medium. In addition, during routine cell culturing of TM3 cells, we observed their ability to withstand long periods of time without replacing the growth medium. Based on these observations, we postulated that TM3 cells would be a good candidate for development into a self-proliferating cell line using unsupplemented serum-free medium.

The research presented here focuses on the establishment of the new cell line (TM3-SF) and its ability to self-replicate. In addition, we have investigated TM3-SF's response to estrogens as measured by increased cell proliferation.

\section{Materials and methods}

Chemicals. Trypsin-EDTA (1X) and Ham's F12 and Dulbecco's modified Eagle's medium (DMEM) (1:1) mixture containing $1.2 \mathrm{~g} / 1$ sodium bicarbonate, $15 \mathrm{mM}$ HEPES, and $3.5 \mathrm{~g} / 1$ glucose was purchased from Life Technologies, Grand Island, NY. 


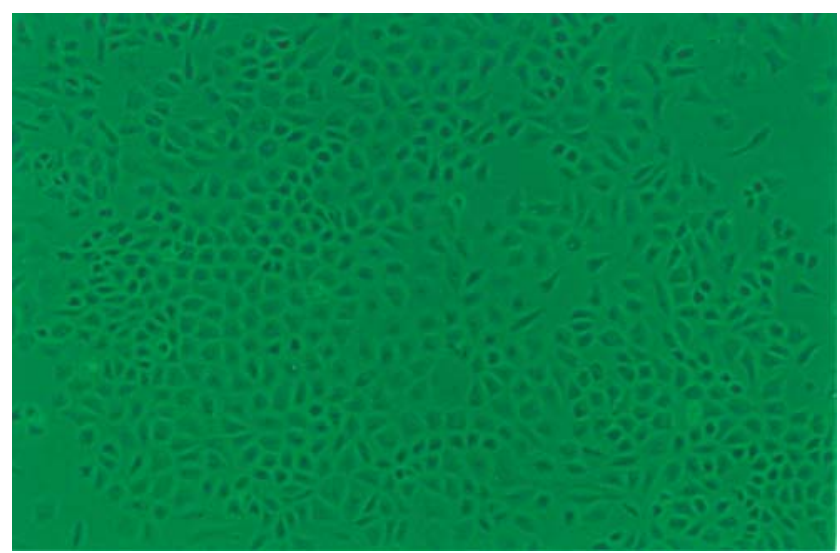

Figure 1. TM3-SF testicular Leydig cells.

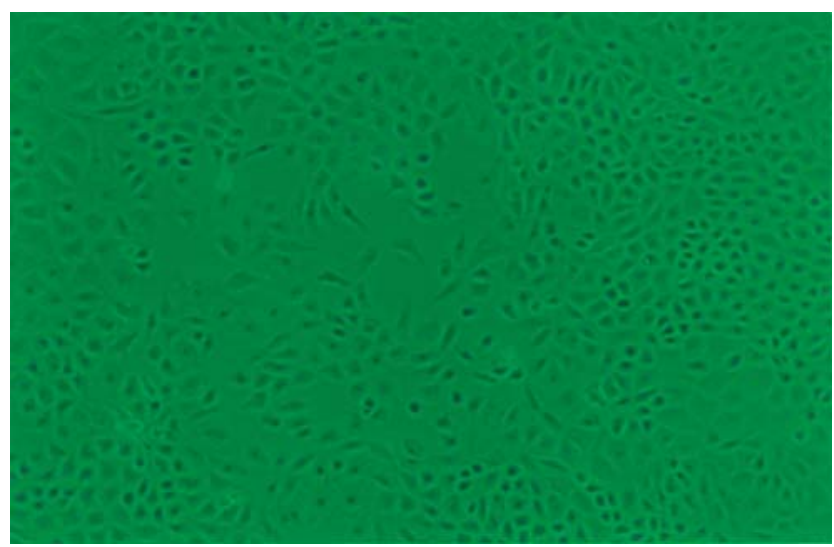

Figure 2. TM3 testicular Leydig cells.

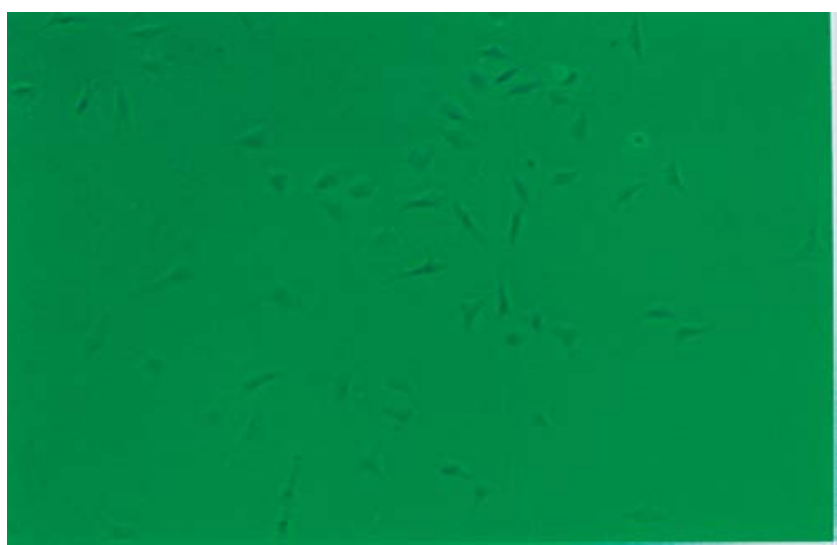

Figure 3. TM3-SF cells $48 \mathrm{~h}$ after plating with $0.000 \%$ serum.

Diethylstilbestrol (DES), tamoxifen, horse serum, fetal bovine serum, DMSO, and propidium iodide were purchased from Sigma Chemical Co., St. Louis, MO. TM3-Leydig cells \# CRL1714 were purchased from ATCC, Rockville, MD. A Corning ${ }^{\circledR}$ $75-\mathrm{cm}^{2}$ culture flask was purchased from Fisher Scientific, Pittsburgh, PA.

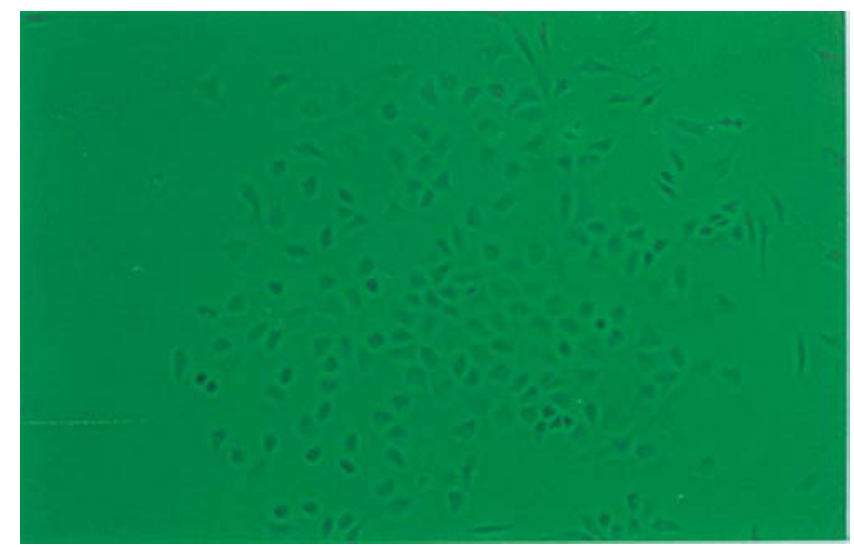

Figure 4. TM3-SF cells $48 \mathrm{~h}$ after plating with $0.007 \%$ serum.

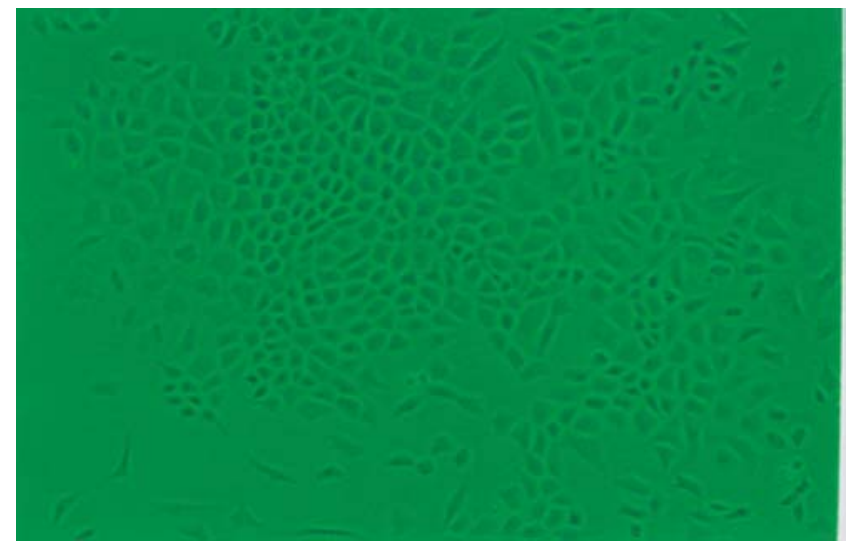

Figure 5. TM3-SF cells $48 \mathrm{~h}$ after plating with $0.015 \%$ serum.

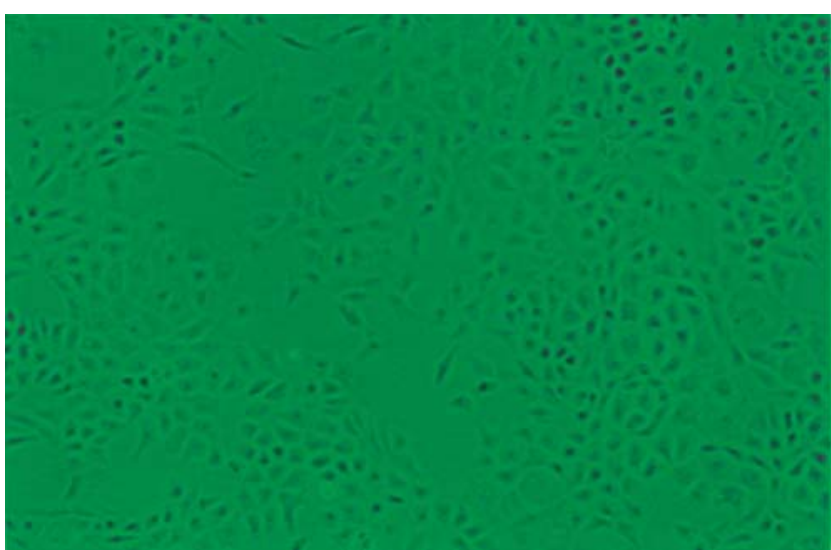

Figure 6. TM3-SF cells $48 \mathrm{~h}$ after plating with $0.100 \%$ serum.

Cell culture preparation. Prior to treatment, TM3 Leydig cells were cultured using DMEM/F-12 medium supplemented with $5 \%$ horse serum and $2.5 \%$ fetal bovine serum. The growth medium was changed once every 2-3 days as needed. Cultures were sub-cultured (1-200) during late log phase growth. 
TM3-SF cell line development. A progressive starvation of the original TM3 cells was used to accomplish the development of the TM3-SF cell line. In phase 1, the cells were plated with the standard growth medium as defined above and grown to a hyperconfluent condition. The cells were then subcultured and the process was repeated. The cells were allowed to remain in the hyperconfluent state for gradually increasing time periods. Once the cells were able to maintain a $\geq 75 \%$ viability for a 2-week starvation period, they entered phase 2 . In the second phase, the cells were plated with normal growth medium, which was replaced $24 \mathrm{~h}$ later with unsupplemented serum-free medium. Once the cells had reached their maximum growth potential, they were subcultured and grown for one cell cycle with normal growth medium. This cycle was repeated until the cells were able to withstand continuous growth in unsupplemented serum-free medium. Phase 3 was then initiated. In this phase, the amount of serum used in the plating medium was progressively decreased until the cells were weaned from requiring standard growth medium for plating. Upon completion of phase 3, the cells were self-proliferating and designated TM3-SF.

Cell proliferation assay. The cells $(\cong 10,000)$ were placed into 48-well plates and allowed to attach for $24 \mathrm{~h}$. The cells were then treated with DES, 17ß-estradiol, Bis-phenol A, or $17 \alpha-$ estradiol. The concentrations tested ranged from $100 \times 10^{-7}$ to $1 \times 10^{-12} \mathrm{~g} / \mathrm{ml}$ in $10^{-1}$ intervals for a total of 6 concentrations. The treatment time for all assays was 5 days. Each trial was conducted in duplicate. After the growth period had expired, all cell cultures were harvested simultaneously and the yields were measured. This was accomplished by removing the medium and adding the cell lysing solution (1X trypsinEDTA). The cells were then counted via the use of a hematocytometer.

Anti-inhibin/activin assay. The cells $(\cong 10,000)$ were placed into 48-well plates, and allowed to attach for $24 \mathrm{~h}$. Cells were then treated with one of 8 different concentrations of antiBa subunit of inhibin/activin, ranging from 2 to $40 \mu \mathrm{l} / \mathrm{ml}$ $(10,000$ units per $\mu 1)$. DES concentrations tested ranged from $100 \times 10^{-7}$ to $1 \times 10^{-12} \mathrm{~g} / \mathrm{ml}$ in $10^{-1}$ intervals for a total of 6 concentrations, and $6 \mu 1$ of anti-ßa was used in the combination studies. The treatment time for all assays was 5 days. Each trial was conducted in duplicate. After the growth period had expired, all cell cultures were harvested simultaneously and the yields were measured. This was accomplished by removing the medium and adding the cell lysing solution (1X trypsinEDTA). The cells were then counted via the use of a hematocytometer.

Statistical analysis. Cell proliferation data were analyzed using the Students' t-test along with an analysis of variation (ANOVA). The overall $\alpha$ was set at 0.05 for the Students' t-test, which was used in the analysis of variation.

\section{Results}

TM3-SF cell line development. The establishment of the TM3SF cell line from the parent cell line, TM3, was accomplished over a 4-month period. Once TM3-SF cells were established, they were allowed to grow for 20 passages before any analysis was completed. The TM3-SF cells remained morphologically similar to the parent cell line, TM3 (Figs. 1 and 2). These cells typically grow in a clonal monolayer, although overlapping of the cells has been observed. The doubling time for TM3-SF cells is approximately 4-5 days, although this can vary with seeding density. This is in contrast to the 16-h doubling time of the TM3 parent cells. TM3-SF sensitivity to the effects of growth stimuli was assayed by exposing the cells to low doses of fetal bovine serum.

The TM3-SF cell line was responsive for increased proliferation, as an increase in proliferation was detected when the cells were exposed to low doses of serum, 0.007, 0.015 and $0.10 \%$ serum (Figs. 3-6). Short-term studies revealed that TM3-SF cells exposed to serum were able to return immediately to unsupplemented serum-free medium without any altered growth characteristics.

Influence of estrogen on growth of TM3-SF cells. The exposure to estrogenic chemicals resulted in a significant $(\mathrm{p}<0.05)$ increase in proliferation when compared to the controls (Fig. 7). DES produced the greatest response as it resulted in a significant $(\mathrm{p}<0.05)$ increase of cell proliferation with all concentrations $<100 \mathrm{ng} / \mathrm{ml}$. DES $100 \mathrm{ng} / \mathrm{ml}$, resulted in a significant decrease in cell proliferation. Maximum proliferation was noted at $1 \mathrm{pg} / \mathrm{ml}$ DES (184.45\%). A second peak in proliferation was noted at $1 \mathrm{ng} / \mathrm{ml}$ DES (166.57\%). Bis-phenol A was the second most potent chemical as treatment resulted in peak proliferation at $1 \mathrm{pg} / \mathrm{ml}(145.26 \%)$ and $100 \mathrm{ng} / \mathrm{ml}$ (138.95\%). Concentrations of $10 \mathrm{pg} / \mathrm{ml}$ to $1 \mathrm{ng} /$ $\mathrm{ml}$ Bis-phenol A resulted in significant $(\mathrm{p}<0.05)$ decreases in cell proliferation. TM3-SF cells were unresponsive to 173 estradiol at $1 \mathrm{pg}$ to $10 \mathrm{ng} / \mathrm{ml}$; however, $100 \mathrm{ng} / \mathrm{ml}$ resulted in a significant $(\mathrm{p}<0.05)$ increase in cell proliferation. $17 \alpha-$ estradiol was the weakest of all compounds tested, although it did produce a significant $(\mathrm{p}<0.05)$ increase in proliferation at $10 \mathrm{pg} / \mathrm{ml}$.

Anti-inhibin/activin assay. The addition of activin/inhibin Ba subunit antibody to TM3-SF cells significantly reduced the ability of these cells to proliferate (Fig. 8). The addition of $2 \mu \mathrm{l} / \mathrm{ml}$ of the anti-ßa subunit antibody was sufficient to reduce growth by $35.9 \%$. The peak reduction of cell growth was noted with the addition of $30 \mu \mathrm{l} / \mathrm{ml}$ of the anti-ßa subunit $(58.95 \%)$. Co-administration of the anti-ßa subunit $(6 \mu \mathrm{l} / \mathrm{ml})$ and DES (1 pg to $100 \mathrm{ng} / \mathrm{ml})$ resulted in a similar reduction in growth as seen with the addition of the anti-ßa subunit alone (Fig. 9).

\section{Discussion}

The development of the TM3-SF cell line is novel as currently there are no reports of any Leydig cell lines that can be maintained under unsupplemented serum-free conditions. A comparison of the cell growth of TM3-SF data presented here with precursor cells, TM3, showed that both cell lines differ in estrogen sensitivity. However, TM3-SF demonstrated a greater mitogenic activity with lower concentrations of DES and inhibition of proliferation at $100 \mathrm{ng} / \mathrm{ml}$, whereas TM3 had its greatest response to DES at $100 \mathrm{ng} / \mathrm{ml}$. The Bis- 


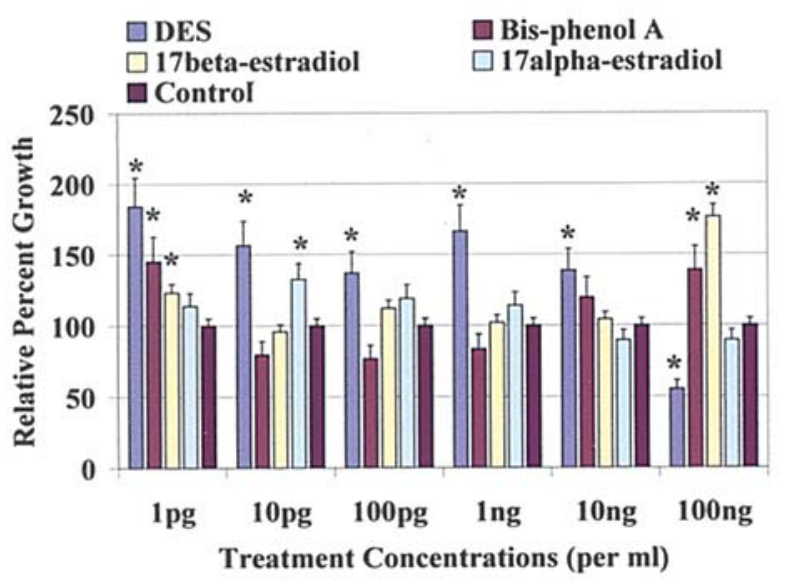

Figure 7. Estrogen-induced proliferation of TM3-SF cells. Data are presented as percent growth with controls set at $100 \%$. Results are from 6 different treatment concentrations $(1 \mathrm{pg} / \mathrm{ml}$ to $100 \mathrm{ng} / \mathrm{ml})$. Exposure time was 5 days for all treatments. Asterisk indicates treatments significantly different from controls $(\mathrm{p}<0.05)$ using the Student's t-test. Error bars $(\mathrm{T})$ represent standard deviations.

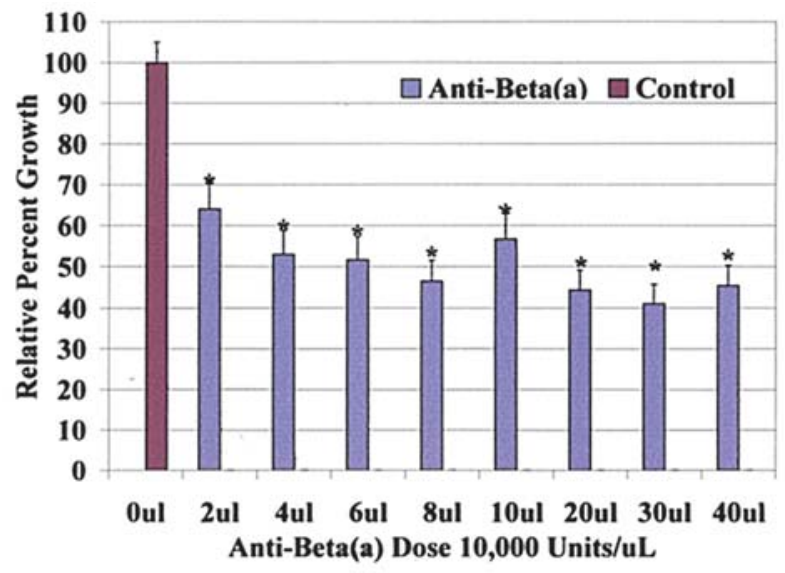

Figure 8. The inhibition of TM3-SF growth by the anti-ßa subunit of activin and inhibin. Data are presented as percent growth with intra-trial controls set at $100 \%$. Results are from a 5-day treatment period. A total of 8 different concentrations, 2-40 $\mu 1 / \mathrm{ml},(10,000$ units $/ \mu 1)$ of anti- $\beta$ a were administered. Asterisk indicates treatments significantly different from controls $(\mathrm{p}<0.05)$ using the Student's t-test. Error bars (T) represent standard deviations.

phenol A-mediated stimulation of cell growth of TM3-SF cells was novel, as Bis-phenol A had no effect on TM3 cells. We also observed a difference in 17ß-estradiol results, as the peak proliferation was noted at $100 \mathrm{ng} / \mathrm{ml}$ in TM3-SF cells. In TM3 cells, 17ß-estradiol had its greatest response at $10 \mathrm{ng} / \mathrm{ml}$ and was remarkably weaker in comparison. The response to $17 \alpha$-estradiol also differs between the two cell lines, as $17 \alpha$ estradiol is able to produce a significant mitogenic response in the TM3 cell line, whereas TM3-SF is non-responsive.

We find the anti-ßa subunit data both remarkable and intriguing, as it is suggestive of a possible mechanism for the self-proliferation of the TM3-SF cell line. It is known that Leydig cells are a primary target for both inhibin and activin. It is also believed that the primary source of activin is the seminiferous cells, whereas the Sertoli cells are the primary source for inhibin (33-35). However, the role of inhibin and

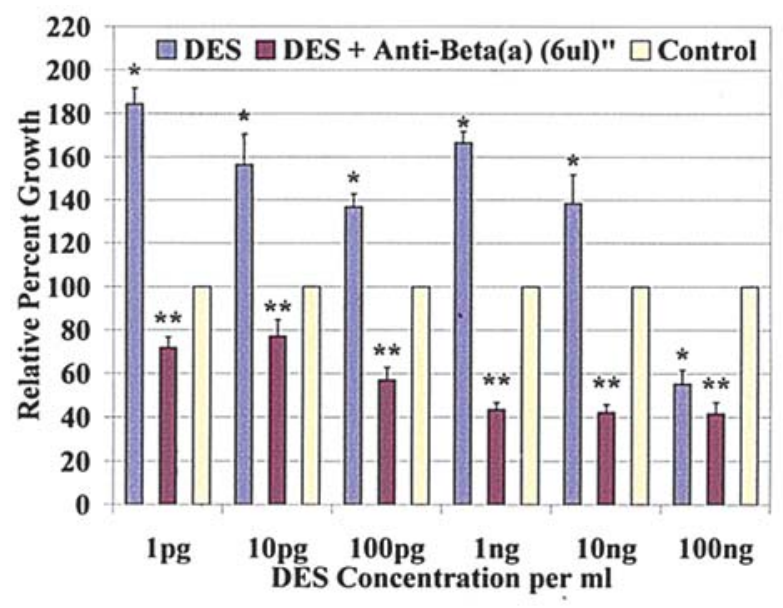

Figure 9. The effect of anti-ßa subunit of activin and inhibin on DES-induced proliferation of TM3-SF cells. Data are presented as percent growth with intra-trial controls set at $100 \%$. Results are from a 5-day treatment period. Treatment concentrations ranged from $1 \mathrm{pg} / \mathrm{ml}$ to $100 \mathrm{ng} / \mathrm{ml}$ for DES, combination treatment consisted of the addition of $6 \mu 1 / \mathrm{ml}(10,000$ units $/ \mu 1)$ of anti-Ba to the same DES treatments. Asterisk indicates treatments significantly different from controls $(\mathrm{p}<0.05)$ using the Student's t-test. Asterisks indicate a significant reduction of DES-induced proliferation of Leydig cells $(\mathrm{p}<0.05)$ using the Student's t-test. Error bars $(\mathrm{T})$ represent standard deviations.

activin in regulation of cell growth is not clear. There are reports that suggest both Sertoli and Leydig cancer cells secrete increased levels of inhibin (36-39).

There are two possible explanations for the data we have presented. First, the gene for activin or inhibin may have been turned on and/or up-regulated in TM3-SF cells. Second, the original cell line, TM3, actually might be a co-culture of Leydig, Sertoli, and/or seminiferous cells. After reviewing the procedure used in the development of TM3, the latter possibility is not likely (40).

The ability for anti-inhibin/activin to block DES-induced proliferation is of interest, as it may indicate a possible mechanism for proliferation. DES exposure may up-regulate both the inhibin or activin gene, and one of the two or both might act as a second messenger for the observed mitogenic effects. This observation may also be explained by binding of DES by the anti- $\beta$ a subunit, thereby decreasing the bioavailability of DES. Currently, additional studies are being conducted using the newly established TM3-SF cell. These studies will investigate further the role of activin in the proliferation of these cells.

In summary, this report presents the novel mouse Leydig cell line, TM3-SF. TM3-SF cells are estrogen sensitive for a cell proliferation endpoint and the observed mitogenic response differs significantly from its precursor cells, TM3. Furthermore, the data presented here suggest that either inhibin or activin may act as a second messenger for DESinduced proliferation, although additional research is needed for the validation of this mechanism.

\section{References}

1. Soto AM, Fernandez MF, Luizzi MF, Oles Karasko AS and Sonnenschein C: Developing a marker of exposure to xenoestrogen mixtures in human serum. Environ Health Perspect 105 (suppl 3): 647-654, 1997. 
2. Fox JE: Chemical communication threatened by endocrinedisrupting chemicals. Environ Health Perspect 112: 648-653, 2004.

3. Sheiner EK, Sheiner E, Hammel RD, Potashnik G and Carel R: Effect of occupational exposures on male fertility: literature review. Ind Health 41: 55-62, 2003.

4. Pieau C and Dorizzi M: Oestrogens and temperature-dependent sex determination in reptiles: all is in the gonads. J Endocrinol 181: 367-377, 2004.

5. Balaguer P, Joyeux A, Denison MS, Vincent R, Gillesby BE and Zacharewski T: Assessing the estrogenic and dioxin-like activities of chemicals and complex mixtures using in vitro recombinant receptor-reporter gene assays. Can J Physiol Pharmacol 74: 216-222, 1996.

6. Jobling S, Reynolds T, White R, Parker MG and Sumpter JP: A variety of environmentally persistent chemicals, including some phthalate plasticizers, are weakly estrogenic. Environ Health Perspect 103: 582-587, 1995.

7. Jung EY, Lee BJ, Yun YW, Kang JK, Baek IJ, Jurg MY, Lee YB, Sohn HS, Lee JY, Kim KS, Yu WJ, Do JC, Kim YC and Nam SY: Effects of exposure to genistein and estradiol on reproductive development in immature male mice weaned from dams adapted to a soy-based commercial diet. J Vet Med Sci 66: 1347-1354, 2004.

8. Vidaeff AC and Sever LE: In utero exposure to environmental estrogens and male reproductive health: a systematic review of biological and epidemiologic evidence. Reprod Toxicol 20: 5-20, 2005.

9. Garner MJ, Turner MC, Ghadirian P and Krewski D: Epidemiology of testicular cancer: an overview. Int J Cancer 116: 331-339, 2005.

10. Safe S: Environmental estrogens: roles in male reproductive tract problems and in breast cancer. Rev Environ Health 17: 253-262, 2002.

11. Ginsberg J: Environment oestrogens. Lancet 343: 248-285, 1994.

12. Giwercman A, Carlsen E, Keiding N and Skakkebaek NE: Evidence for increasing incidence of abnormalities of the human testis: a review. Environ Health Perspect 101 (suppl 2): 65-71, 1993.

13. Moller H, Premer A and Skakkebaek NE: Testicular cancer, cryptorchidism, ingual hernia, testicular atrophy, and genital malformations: case-control studies in Denmark. Cancer Causes Control 7: 264-274, 1996.

14. Rajpert-De Meyts E and Skakkebaek N: The possible roles of sex hormones in the development of testicular cancer. Eur Urol 23: 54-61, 1993.

15. Sharpe RM and Skakkebaek NE: Are oestrogens involved in falling sperm counts and disorders of the male reproductive tract. Lancet 341: 1392-1395, 1993.

16. Clegg ED, Cook JC, Chapin RE, Foster PM and Daston GP: Leydig cell hyperplasia and adenoma formation: mechanisms and relevance to humans. Reprod Toxicol 11: 107-121, 1997.

17. Li JJ and Li SA: Estrogen carcinogenesis in hamster tissue: a critical review. Endocr Rev 11: 524-531, 1990.

18. Li JJ, Gonzalez A, Banerjee S, Banerjee SK and Li SA: Estrogen carcinogenesis in the hamster kidney: role of cytotoxicity and cell proliferation. Environ Health Perspect 101 (suppl 5): 259-264, 1993.

19. Li JJ, Li SA, Oberley TD and Parsons JA: Carcinogenic activities of various steroidal and non-steroidal estrogens in the hamster kidney: relation to hormonal activity and cell proliferation. Cancer Res 55: 4347-4351, 1995.

20. Crisp TM, Clegg ED, Cooper RL, Wood WP, Anderson DG, Baetcke KP, Hoffmann JL, Morrow MS, Rodier DJ, Schaeffer JE, Touart LW, Zeeman MG and Patel YM: Environmental endocrine disruption: an effects assessment and analysis. Environ Health Perspect 106 (suppl 1): 11-56, 1998.

21. Venizelos ID and Paradinas FJ: Testicular atrophy after oestrogen therapy. Histopathology 12: 451-454, 1988.

22. Sapino A, Pagani A, Godano A and Bussolati G: Effects of estrogens on the testis of trans-sexuals: a pathological and immunocytochemical study. Virchows Arch 411: 409-414, 1987.
23. Gooren L: The neuroendocrine response of luteinizing hormone to estrogen administration in heterosexual, homosexual, and trans-sexual subjects. J Clin Endocrinol Metab 63: 583-588, 1986.

24. Yamamoto T, Li I, Uchida N, Nishizawa Y, Yamaoto R, Terada N, Taniguchi H, Matsumoto K and Sato B: Stimulation by estrogen and progesterone of the in vivo growth of transformed murine Leydig cells at the limited early phase of growth. Anticancer Res 12: 1339-1345, 1992.

25. Toppari J, Larsen JC, Christiansen P, Giwercman A, Gradjean P, Guillette LJ Jr, Jegou B, Jensen TK, Jouannet P, Keiding N, Leffers H, MacLachlan JA, Meyer O, Muller J, Rajpert-De Meyts E, Scheike T, Sharpe R, Sumpter J and Skakkebaek NE: Male reproductive health and environmental xenoestrogens. Environ Health Perspect 104 (suppl 4): 741-803, 1996.

26. Deshmukn AS and Hartung WH: Leydig cell tumor in patient on estrogen therapy. Urology 21: 538-539, 1983.

27. Bercovici JP, Kerlan V, Monguillon P, Fournier G and Nahoul K: Mid-term and long-term outcome in Leydig cell estrogen tumors. Ann Endocrinol 55: 181-184, 1994.

28. Valensi P, Coussieu C, Killian E, Tran-Quang N, Attali JR and Sebaoun J: Leydig cell tumor estrogen secretion: suppression by a gonadotropin releasing hormone agonist. J Endocrinol Invest 14: 583-589, 1991.

29. Catala Bauset M, Girbes Borras J, Carmena-Ramon R, Real Collado J and Gonzalez-Bayo E: Gynecomastia and Leydig cell tumor. Ann Med Interne 14: 131-134, 1997.

30. Soto AM, Sonnenschien C, Chung KL, Fernandez MF, Olea N and Olea-Serrano F: The E-screen assay as a tool to identify estrogens: an update on estrogenic environmental pollutants. Environ Health Perspect 103 (suppl 7): 113-122, 1995.

31. Du Mond JW, Singh KP and Roy D: The biphasic stimulation of proliferation of Leydig cells by estrogen exposure. Int J Oncol 18: 623-628, 2001 .

32. Du Mond JW, Singh KP and Roy D: Regulation of the growth of mouse Leydig cells by the inactive stereoisomer, $17 \alpha$-estradiol: lack of correlation between the elevated expression of ER $\alpha$ and difference in sensitivity to estradiol isomers. Oncol Rep 8: 899-902, 2001.

33. Mather JP, Zhuang LZ, Perez-Infante V and Phillips DM: Culture of testicular cells in hormone-supplemented serumfree medium. Ann NY Acad Sci 383: 44-68, 1982.

34. Depuydt CE, Mahmoud AM, Dhooge WS, Schoonjans FA and Comhaire FH: Hormonal regulation of inhibin B secretion by immature rat Sertoli cells in vitro: possible use as a bioassay for estrogen detection. J Androl 20: 54-62, 1999.

35. Jarred RA, Cancilla B, Richards M, Groome NP, McNatty KP and Risbridger GP: Differential localization of inhibin subunit proteins in the ovine testis during fetal gonadal development. Endocrinology 140: 979-986, 1999.

36. Iczkowski KA, Bostwick DG, Roche PC and Cheville JC: Inhibin $\mathrm{A}$ is a sensitive and specific marker for testicular sex cord-stromal tumors. Mod Pathol 11: 774-779, 1998.

37. McCluggage WG, Shanks JH, Whiteside C, Maxwell P, Banerjee SS and Biggart JD: Immunohistochemical study of testicular sex cord-stromal tumors, including staining with anti-inhibin antibody. Am J Surg Pathol 22: 615-619, 1998.

38. Riopel MA, Perlman EJ, Seidman JD, Kurman RJ and Sherman ME: Inhibin and epithelial membrane antigen immunohistochemistry assist in the diagnosis of sex cord-stromal tumors and provide clues to the histogenesis of hypercalcemic small cell carcinomas. Int J Gynecol Pathol 17: 46-53, 1998.

39. Yamashita K, Yamoto M, Shikone T, Minami S, Imai M, Nishimori $\mathrm{K}$ and Nakano R: Production of inhibin A and inhibin $\mathrm{B}$ in human ovarian sex cord stromal tumors. Am J Obstet Gynecol 177: 1450-1457, 1997.

40. Mather JP and Phillips DM: Establishment of a pertitubilar myoidlike cell line and interactions between established testicular cell lines in culture. J Ultrastructure Res 87: 263-274, 1984. 